\title{
The Home Defence Bill as Affecting the Volunteers
}

\author{
Lieut.-Colonel F. W. Haddan
}

To cite this article: Lieut.-Colonel F. W. Haddan (1889) The Home Defence Bill as

Affecting the Volunteers, Royal United Services Institution. Journal, 33:148, 519-536, DOI:

$\underline{10.1080 / 03071848909416502}$

To link to this article: http://dx.doi.org/10.1080/03071848909416502

\section{曲 Published online: 11 Sep 2009.}

Submit your article to this journal $\sqrt{6}$

山 Article views: 5

Q View related articles $\sqsubset$ 
Fridas, March 22, 1889.

Lietr.-Gexeral Sir II. EVELYN WOOD, v.C., G.C.M.G., K.C.B., in the Chair.

\title{
THE HOME DEFFNCF BILL $\Lambda$ S AFFECTING THE VOLUNTEERS.
}

\author{
By Licut.-Colonel F. W. HADDAx, 4th Volunteer Battalion, tho \\ Queen's Rojal West Surrey Regiment.
}

\section{Introductory Remartis.}

I wisil to offer a few preliminary remarks as to the reason for sclecting the title I havo chosen for my papor.

- All aro probably aware that tho Bill introduced in 1858 wins entitled the "National Defence Bill," and that it contained certain clauses atfecting the Voluntecrs, which clauscs wero subsequently withdrawn, and in consequenco has arisen tho raison d'étre of the paper I purpose reading to.daj.

In any case it wonld be manifestly ont of placc, especially in an Institntion such as this, for me to attempt to discuss the details of "National Defence," which includes the naral services of our Flect, and the duties of the Army at large, subjects which I would not profess to be able to bandle.

I have therefore confined myself to the question of the dropped clanses, and limited msself to what concerns the Volunteers solcly, and have thereforo with this view entitled my paper "The Home Defence Bill as affecting the Yolnutcers."

1. That great divergence of opinion exists as to the probable effects of tho recent Government proposals is snfficiently manifest; but to which side of the controrersy the "right" belongs is not yet by any means asured.

2. The olject of this paper is, therefore, not so much to set forth my own individual views as to initiate a discussion on this rery inportant subject, and so enable all shades of opinion to be expressed, and that in a manner not contrary to discipline and the regulations.

3. That no definito opinion of the Voluntecrs as a whole has been obtained is certain, and I cannot but feel that the abstention from agitation on this matter, one way or the other, is about the best proof of discipline and self-control that the Volunteers could have afforded. 
I, mysclf, as doubtless nauy others, felt the propricty and necessity of awaitiug a request from the authoritics in regard to my opinion, as representing iny battalion; and it is only becauso no such step appcars to be contemplated by ms superiors that I hare sought this opportunity of raising a discussion on the subject.

4. I strongly deprecate tho linndling of subjects such as this by tactical socicties, which aro formed for tho distinct purpose of studsing tactics and practising Kricrspiel. A recent caso at Lircrpool affords an example of the troubles that mny cnsuo from such socictics attempting to deal with ordinary matters of a military nature.

5. We are of course all aware that-thcre arc, in our branch of the Service, several Members of Pnrliament who hare not hesitated to express their ricks, and who, probably, may havo considered that because the opinions adranced were theirs, or as representing their orm particular battalions, they thereforo necessarily represented the opinion of the whole Voluntecr Force.

6. What may truly represent the views of a "gentleman-private" or "class" corps, nuag be utterly unsuited to and divergent from thoso of a "working-man" or "mass" corps, and the same differenco of circumstances may be found in the case of "country" as distinguished from Metropolitar or "town"..corps.

7. Under such circamstances, therefore, it seems most desirable that all sides should be heard, and I wish to statc distinctly that I do not at tempt; or wish to cudca rour, to scttle this question according to my orn views, which I express simply as my own, and in order to found a groundrork for argunent whether for.or against mc.

8. Whaterer opinion is found to prevail would be loyally adopted by me, for I loold that tho majority should always exercise their strength when their case is proved.

.9. Witl these propisoes, I will now procecd to stato my riews as to the wisdom and policy of tho course.taken by tho authoritieg, in sugfesting that the Voluntcers slould allow thenselves to be placed under new conditions of serrice, as originally proposed in the National Defence Bill, 1888.

- 10. Ihe first intimation receired of the proposal was when the National Defence Bill was submitted to Parliament, and it contnincd certain clauses whereby the present conditions of voluntecr service would be considerably altered. $\Lambda$ short discussion only ensued in Parliament, wben a few members of the House, who aro also Volnnteer. Officers, gave their opinions for or against, and a few other Officers wrote to the papers; and finnlly the clauses wero withdrawn without, as I contend, the gencral opinion of tho Toluntecrs havine been in any sufficient way ascertained. Thus heartburnings hare been caused which might haro been aroided had a somerhat different course (such for instance as a prelininary-confidentinl circular to Oflicers Commanding) been adopted.

11. 'The authorities may, howerer, with some considcrable show of reason, pleal that they werc justified in taking the course they did, seciug that in ond recent Eggptian troubles they had offers of serrice 
from several Commanding Officers to place their corps at the disposal of the authorities.

12. That they were ever'scriously meant I take lcare to donbt; I would characterize such offers as unsound spasms of frenzicd zeal, or as an attempt to "adrertiso" a corps. Had an offer so mado been scrionsly cntertained and accepted, I ventare to assert that it would hare been found to be a mere flash-in-the-pan.

13. T'o offers sach as these may therefore in a great measure be traced the circumstances under which the mensure was introduced into Parliament.

14. Whatover the faults of the past, we hare now to deal with the case as it stands, and the point. I saggest for discussion is : "Woukl the Volnoteers as a whole be willing, and alle, to gire their scrvices in tho mauner suggested in the Home Defence Bill, arid eren if they were, would it bo desirable, in tho best interests of the force, quâ Volunteers, that thoy should be so called upon?"

15. As regards the personal willingness of every man in the force $I$ haro no shadow of a doubt, but as regards his ability I have very gravo doubts, for as a busiriess man myself I am only too well awaro of the objections raised by many emplojers of labour to their assistants being connected with the force, and eren when they are known to bo so connected, not the slightest facilitics are afforded, in ver's mans cases, if voluntecr duty at all clashes with busincss.

16. It is to this latter canse that I attribute the great difficulty of getting men to the ranges for musketry practice, which ander present inles must necessarily take place in. dnylight, and thereforo (cxecpt in some cases on Saturdaj half-holidass and bank. holidajs) in business hours.

17. To emplojers of labour, such as the foregoing, I would point out the unenviablo position in which they would be, should no Volunteer Force exist; and I sas, broadly. that it is not only. their duty as citizens to aid by eveiy means in their power their patriotic cmployes, but that, taking even the most selfish motires, it is their distinct interest to do so, for if the Toluntecr Force be not supported, and greater facilities given to its members, the time may come when cither the Army must be increased, or the militia ballot enforced, either of which will inevitably affect thcir pockets; or else a Home Defence Tax nas hare to be imposed especially on them, they being not only unwilling to aid in tho general burden of duty to the State, but for positircly acting as obstractires to others more nobly, patrioticall $f_{\text {, }}$ and generously inclined.

.18. In these dass of an enlightened press, and of publicity and adrertiscment, I venture to assert that no firm of any standing would dare to say out in tho faco of day that thej wonld not allow their emplojés to bo rolunteers; even under tho Home Defence.Clavise; but:I am equally. sure that there: are many firms who fcel, and sub ros $\hat{a}$ act, in this manner; and it is only exposure that will remedy this sad trait of money-grubbing before patriotigni, and which. has perhaps justified the remarks of forcign critics that we are "a. nation of shopkeepers.": I hare scen it. stated lately that some. of .Coloriol 
Laurie's men have had to resign, owing to their emplojers refusing to allow them to remain as voluntecrs. I should like to know the name of sach firm, which I would publish in orders and in the press.

19. Tho foregoing is, however, but one branch of tho "ability" question.

20. Volunteers are necessarily civilians first and soldiers afterwards, and probably 95 per cent. of the force as a whole aro directly engaged in professions, businesses, or occupations: on which they and their families are actually dependent for their lirelihood.

21. To interfere unnecessarily, or even to gire men cause to think that their means of livelihood will be, or cren mas be, interfered with unnecessarily, is a very scrious matter, and it is on this rock that the Government proposals have for the moment suffered shipwreck, mainls, as I beliere, by reasori of the Officials not haring sufficiently informed themselves of the opinions of those most interested. It is true that there was the general safeguard that no man at present in the force was obliged to go under the new Act, bat only those who desired, or those now joining the force.

22. The nero poicer to call out the Voluntcers as proposed is nothing, for it may be safely assumed it would nerer have been pat in forco unnecessarily; but to make this power of any practical utility, tho men would hare to be escreised, in peace-tine, in the performance of the rarious duties they might one day hare to perform in real carnest. It was therefore felt by some that this power to call out might, to a limited extent, be nsed as a lever to get. men to undertake duties in peacc-timo which might bo of tho greatcst utility and adrantage to them, but which they could not readilyadapt themsclies to, or get their employers to assent to, by reason of the naturo of their ciril arocations.

-23. The withdrawal of the clause from tho Act cannot but act prejudicially on the force in the cyes of the genernl public; for although tho people of all classes are so intimatels connected with it, they aro not arare of tho wholo conditions, and they will bo apt to think that the Volunteers are shirking a proper daty, which the anthorities havo asked them to discharge, and this in the face of the knowledge they possess that a considerable sum has lately been awarded as capitation graut; and it cannot but hare a marked effect, unless properly put before them, on the praiseworthy effort of the Chief Magistrnte of London to raise a fund for 'the better equipment of the Metropolitan corps, as to the absolute necessity for which there is no doubt whaterer.

24. No Voluntecr worthy of the name is desirous of slirking ang duty compatiblo with the due discharge of his first duty to his family and himself; and the rery desire of some to show that they are not so shirking mas, not improbably, lead to thcir engaging in a matter whercof tho possible consequences may not be apparent on the surface.

25. It is assuredly no part of tho Voluntecr's duty to undertake tho work of the Arms proper, nor to onst the militia, which is the constitational force of this countrs, and any steps tencling in this 
dircction must, in the true interests of the force, be carefully watched.

26. Doubtless tho authorities, with a praiserorthy striving after. economy, thought the time had come, after the recent boon of $60,000 l$. a year increased grant to the force, to ask something more in retarn than the grcater stringency of musketry practice; but the Volunteers, on their side, felb and knew that the sum granted only makes up the arrears of many sears' neglect, and can only be counted as a payment for past services and liabilities, and as an carnest of better things to come. In that light it was regarded, and due thanks and praise hare been given to the anthorities for the boon they granted.

27. Sapposing the clause of the new Defence Bill to bo adopted by the force, I should certainly expect that my men, by adopting fresh obligations, should most certainly bo thoroughly equipped and fitted in return, to take their place in the field if and when required. The present Act contemplates and sanctions the payment of three guineas to each man, for equipment, if called out, and I should want this money to bo granted now, so that the necessary preparations might be made in pence-time, and tho men trained in transport dutics, camp cquipage, the use of entrenching tools, and so on.

28. Quitc enough (if not too much) has already been asked at our hands. We have given our time, and our money, whilst othera, on whom a duty derolres also, haro giren nothing. It is not too much to ask, if the pressure of tasation be felt to bo too heavy to warrant the increase of our standing army, that, at least, those who have borne no part of the State's burden should first be called upon to suffer in purse, if they will not in person.

29. Then, supposing the necessity to arise, by all means ask your Volunteers to make fresh sacrifices, but in so doing bo not niggardly in recompensing them for the increased daties and liabilities imposed, especially when it is well known, all the world orer, that the force is the cheapest (and probably erer will be the cheapcst) that any conntry erer possessed, founded entirely from patriotic motives, and in no sense mercenars, and bat for which some form of conscription, so hateful and antagonistic to an Englishman, and so baleful in its effects on our neighbours, would hase to be resorted to.

30. We rant no pay whatever (except we be called on active service), and we cordially sympathizo with erery effort made to render us better soldiers and more fit to take up and perform our duties should tho necessity ever arise.

31. Moro especially do I appreciate the riews of H.R.H. the Commander-in-Chicf, espressed in the letter of service to the new Volunteer Brigadiers, that to bo prepared for all eventualitics we must practise in peace-time, and hare erergthing in readiness.

32. How to practiso mobilization, even on a small scalc, is, howerer, a very difficult matter for us, for tho necessity which this involres of interfering with business arocations has not been sufficiently mado lnown to civilian cmplogers of labour; and they would andoabtedly vesent, in many cases, the desires of their people to avail themselves 
of the chance of practising mobilization, because they wonld not apprecinte the importance of the issues involved.

33. Many of the men who now go to Aldershot; or to camps and marching columns, give up their only holidays. Here, of conrse, the employer cannot interfere. It, howover, speaks well for the rank and file that, in these days of cxpress speed labour, thousands of men are found willing to give up their only dass of rest to perfect themselres in their duties as soldiers. It must, horrover, bo borno in mind, that all cannot obtain their holidass at the fixed times of camps and Aldershot (in the early part of August), and the nuthorities wonld do well to consider whether men, who are quite willing to gire up their holidajs whenever they arrire, conld not be accommodated at military stations, eren if only a company could be got together for the benefit of association with the regular forces, and the loarning of camp routine, and outpost and outdoor dutics.

34. In fact, tho authorities must endearoúr to nake their offers more elastic and suited to the capacities and abilities of the Voluntecrs, for to expect or hope thiat any considerable number of the force can ever be assembled, cren for a weck, at one fixed period, shows a marked misappreciation of what the Voluutcers can possibly perform. In this connection I cannot too strongly urge the advisability of having attached to the Headquarters Staff the rery smnitest Adjatant of Volunteers that can bo obtained, so that his knowledge might be made arailable, and we should thus doubtless obtain many reforms, tho wecessities for which are unknown to the authoritics, guided as they aro cntirely bs the opinion of regalar Officers, who, with the best possiblo intentions, have, so far as our interior economy is concerncd, but a rery saperficial knowledge. I wish, nt this point, to remark that I hare not tho slightest intention of convesing nny impression that the regular Officers (to whom we ove so much, and represented as they aro by our gallant Chairman, than whom a better friend the Volunteers never had) are notldoing all they can for oul branch of the Service. It is ouly in the matter of details, which tend to make the machine more smoothly; that I think a regnlar Officer who has scrred as an Adjutant might possibly prore of grent assistance.

35. Assuming that the recalcitrant emplojers of labour, cither by means of the public press or by the threat of a special Home Defenco Tax, become moro patriotic in their bearing towards the force, there would set remain to bo solved the problem of whether, in the interest of the force itself, it is desirable to proceed on tho lines set forth by the anthorities.

36. We hare already a special Railway Corps, recruited at Crewo from the London and North-Western Kailway, and another is just. bcing formed in London; though in this latter case the additional railway companies are to be attacled to an engiuecr corps, raised under ordinary conditions. Here we hare a direct examplo of men serving in tho same battalion under different conditions of serrice.

Again, in tho Post Office Corps, we find the same thing. Some men actually base been on. service and some liable to go, and with 
the prospect of deferred pay-whilst others serre under the ordinary conditions; and no ill effects aro visible.

37. Some good friends of the volunteer movement maintain that it would be fatal to its continued prosperity to establish two sorts of service; that is, one for "active" and one for "passive." That esample already quoted docs not, howerer, bear out this riew. I do not find that in any of these corps the men are thought more of because they can engage for activo service, nor do I find in the opinion of the general public, or the Voluntecrs themselres, that these corps stand in any different position to the general run; whilst I most cordially support their adoption of the chances offered them to become, by reason of their special avocations, of still greater service to thcir conntry.

38. In the Army proper we find corps d'élite, such as the Bodygaard, tho Lingincers, and the Rojal ditillery, and to ms mind it is only human nature to expect to find similar conditions in tho Voluntecrs. I would, therefore, let erery corps do as it pleases, in offering to go nader tho new Act, feeling assured it will bo done for the common welfare of the country, and that no stigmn would attach to any reginent, if it be so cirenmstanced as not to be able to respond as frecly as others to the new deniand.

39. I woald, howerer, as I lave before stated, cxpect that the corps so circuinstanced as to undertako the new liabilities should absolutely bo cquipped and fitted out by the anthorities to cnable them to perform their now duties if called upon.

10. That all will respond, shonld over the call of duty bo heard in carnest, I firmly beliere; but I would not myself stand in the ray of one single man offering better serrice to his countrs, for fear of creating two classes of scrrico amongst the Voluntecrs, especially as in the cascs already quoted where a dual service docs exist, not the slightest inconrevience is found to accrae.

41. For sach corps, or such men, howerer, I certainly elaim the greater attention and support; on the grounds of mere commercial morality. If higher dnties are cxacted, and can be gicen, bs all means haro them, and pay for them, according to the ordinars rulo of supply and demand.

42. I shall certainly feel no sense of enry or disappointment supposing my own battalion wero anablo to do as much as others. On the contrary, I should know that mJ men, weighing their just responsibilities, either do or do not desire to undertake fresh dnties; but whaterer the upshot, I should feel convineed they had acted on judgment and not impulse, and what thes liaro undertaben or did undertake, they would nssuredls carrs out.

43. It may not bo out of place, in conclusion, to remark that the Yeomanry nre now under the $\Lambda$ ct, and the Rojal Naral Artillery Volunteers also, aud thes can be called out for actual service whenerey the Rosal Naval Rescrve is called out. such Rescrre being to tho Nary what the Drilitia represents to the Army. 
The Crstryss: : Beforo calling upon Oficcrs to address the mecting I should like to refer to three paragraphs in the paper, because I do not think it is much uee discussing things which aro not facts. I refer to paragraphs 10, 33, and 34. The lectures lias pointed out to us as part of the last paragraph, $3 l$, that it would be adrisable to attach our smartest Adjutant to the Headquarters Staff of the drmy in order that the Headquarters Staff wight be closely posted up as to the feelings of the Toluntecrs themselres, and might bo able to inform the Commander-in-Chicf how much thes can do and what thes ought not to be asked to do. But, gentleincn, rd liave already got that machiners, and, I think, cristing in a much more perfect form. Whether ro take aclrantage of it is nnotlice question. We hare a General Offece in conmand of cach district, and it is their duts to clo crerything they can to assist the Voluntecrs, to becomo closely identified with them, and to know the wiolies and wants of erers corps. Assuming, for a moment, that we take our smartest Adjutant from the London Scottish, or the Artists, or the Westmingter, he would onls represent that one corps out of the vlole district. In the dietrict containing 18,000 Voluntecrs, from which I hnro rcecntls come, there are many corps, and all with different wants and requirements. I bclong inyself to a corps which has gone into camp for sir days in nine sucecsire jears. They did not find tho diffeutics which other corpz do; but if they wero factory people, and the fuctorics had to stop work, it rould be actually imposible that they could do it. If there is a unistake, as implied by the lecturer, I do not think that rould be the way of mending it. I thint the only way would be that we, as Generals ourselres, should take much more interest than wo harc done in tho Yoluntecrs. I think the lccturcr has made in crror in theae three paragraphs in supposing that we do want anj $\Lambda$ djutant, lowercr emart, to inform the ddjutant-General fliat jour wishes nre; and if he tried to do it I fear lie would not gire sou, and he would not gire us, satisfaction.

Coloncl Howand Trscesr, MI.P. : Sir Erclsn Wood, I think all Volunteer OfR. cers who arc prescnt will agreo with me that the force is rery greatly indebted to Colonel Haddan for haring prepared so raluable a paper. ile has laid his riers before this mecting with rers great clearncss, and I hare no hesitation in saying that thes are riems which aro shared by a considerable proportion of Voluntecrs. As he rightls sajs, paragraple lit is the unost important one of his whole paper, and ho suggests thig point for discussion: "Would the Yoluntecrs; ns a wholc, be willing and alle to gire their serrices in the manner suggested in the Home Defenco Bill, and, cren if they were, rould it be desimble, in the best intercsts of the force, que Volunteers, that thes sliould be so called upon?" I should like, with the permission of the necting, to say one rord upon that pangmph, and upon the conclusions which one m.s dras from it. But, in the first place, let me point out that which mas not hare been noticed by all, nancly, that there is no such Bill now before the House of Commons as "The Home Defence Bill." Thicre was last year the National Defence Bill, in which the clause to which Colonel IIaddan has so well referred, was incorporited. The clauso affecting the Toluntcers was taken out of the Bill, and the Bill without tho roluntecr clause passed. But it is not at tho present time before the Housc of Commons. I mseclf aun anxiously hoping that it will be re-introduced in some form or another. In saying that, of course I $\mathrm{nm}$ only representing my indiridual opinion. I must be careful not to fall into the crror that Colonel Ḣaddun suggests some of uz in the Iouse of Commons haro fallen into, namels, of represcnting our indiridmal ricks as being tho ricks of the wholc force. Hasing talen rery great intercst in this subject, and differing from somo of $\mathrm{my}$ colleagues in the House of Commons as to the fecling of the Foluntecrs in this matter, I lare no licsitation in saying that we aro greatly indebted for this opportunity of discussing it, and we much appreciate the prescnce of Sir Erclyn Wood, General Frimantle, Colonel Struces, Sir Harclock Allan, and other memhers of Parliament who tale the greatcat interest in the Voluntecr Force. Personally I nnswer this question in paragrapl 14 of the paper vers strongly in the a firmative. I belicve that the Voluntecrs would, as a whole, be willing and able to gire their serrices in the manner whlch mas suggested by the National Defence Bill of last sear, and I think it would be rery greatly to the interests of the force if they urere called upon to do so. Under the present condition of things, that is, the 
Toluntecr Act of 1863, Toluutcers can only be called upon when there is actual clnnger of invasion, and that would nican, I tako it, whicn tho enems is off tho cosest. There is nobody who has had anjthing to do with the Voluntecrs, howerer great reliance they may place in the roluntecr morement, and whaterer confidence thes may fecl in the conatitution of tho force, who doce not recognize that some wecks, at the rery least, of preparation will be absolutely ceential before the force can be reads to tale the ficld. That being 80 , I do think it is most unwise that the country should be limited by the present Act of Iarliement to calling upon Folun. teers until the hour of preparation is orer. I think that there would be no danger Flsterer if the clause of last jear had becn allowed to pess. No Voluntecrs who are now serring would bo required to enter into ans fresh engagement unless they were willing to do so. I feel strongly, and I desirc strongly to support what Colonel Haddan lias so $\mathrm{xcll}$ said, that the fear of creating two clawes in tho Voluntecrs is purcly msthical. I do not think the smallest rcprosech would attach to any einglo indiridual who found himeelf unable, eitler from family errices or professional emplosinent and otber causes, to gire that grcater amount of scrrice which was contemplatod by the Act. I beliere a rery large proportion of emplosers of labour in this country fully recognize the onormous adrantege of the Folunteers, an adrantage not only in a military capacity, but a civil and rooral adrantage. Oac firn is rers much in my mind at the present time-lhere is no rcueon in the world why I elould not mention tho nane-Mcsers. Shoolbred and Compans, whe support the Voluntec Force in a most libersl and gencrous manner, who cquip and support a company cntirely at their onn crpenee; who rent a rage for it; who ongage inotructors for it, and do crerything they possibly can to promote the efficiency of this compang-doubtless, in some mcasurc, from patriotic motives, but also, I am quite sure, because they believe, and their experience teaches thom, that the rery beet men in their employ are those who devote their leisure time to plassical derclopencnt rather than to the diseipating amusements which are open to them in oller channcle. And if I meation tho name of this firn it is by no means becauso they aro superior to other industrisl frms-for there are numerous busincss houecs, not only in London but in other parts of the country; in Yorkehire I lnow ecreral, in Sheficld screral, who take exactly the rame rice, that the healthy recreation of their emplosés is a matter to thom of rery sorious considcration. They know it is nuch to their adrantago for their men to hare their cmulation fircd, their honourable ambition smused by military exercisce, rather than that their energics should be sapped by plesgures impairing their efficiency for businces. Nor upon this National Defence Bill of last year I took the opinion of everal largo cmplojers of labour-some of the largeat firms in Yorkshire, emplosing 10,000 and 12,000 bends, and from all I reccired tho same rerdict-that they did not sco ansthing in the prorisions of this Bill which would prevent their retaining the serrices of any single indiridunl. Holding, then, the riews which I do, lnowing from personal experience and from haring taken, in some mcssure, the feeling through the Captains of companics of the Queen's Westminoter Tolunteers, which I hare tho honour to command, it was upon that ground I strongly supported the rolunteer clause in the Bill last acssion. I bope that there may be a full snd free diecuesion, and I hare crtremels littlo doubt that tho result will be to ehow that this mecting and a rery large proportion of the Yoluntecr Force cordially agrees with Coloncl Haddan, and is znoet anrious to support the Sccretsry of State for War, and our most excellent friend General Fremantlc, the Deputy Adjutant-General, in erery step, in crery messuro which may be undertaken to improre the efficiency and increase thic utility of the Volunteer Force.

Major W. L. HrıIE : I hare been, Sir, for rather moro than trenty-nine years in the force, nnd from my experience I beliere that jou cannot ank the Voluntecrs for more than they arc resds to gire, within thcir ability. I am only going to spcak on one point on this occasion, as I agree with the lecturer on all points. I believe that no Bill introduced into Parliament rould be perfect unless prorigion rere made in it for the wircs and families of men whilst cngaged on actire ecrrice, or axay from their cinplojment, as well as a prorioion for the result of actire service rhen your men are lilled or wounded. Wre must. remenber this, that men taken for actiro ecrice kould be taken aras from their cmplojment, and there is no doubt that

roL. XIXIII.

23 
90 percent. of the Voluntecr Forec are incelinnicz, or cinployes of one sort or another, entirely dependent, with those belonging to them, on their carnings from weck to weck. The Gorernment nuust look this fact in the fince, that in the absence of the irealuinners of the families, they tcill hace to provide for those families. I aun perfectly certain of this, that it rould take all the go out of the wen if thes line that whilst thes wero fighting for their countrs thicir families irere Icft dependent on cliarity of anj sort. "Those vircs and families must fecl that thes are cntitled to demand support from the Gorernment, and the men must know for a cerlainty that their familics, uill be taken cari of in their absence by tho 39 millions-for thind is what it comes to-of the stas-at-homes, and the amount of allorance settled beforehsnd by Act of Parliamcat, thus giving the men the option of resigning during peace if the ferme were not satisfuctors. I hare nothing further to say; I lnow for misself whot I should do, and I lnow from thousanils of unch who have pussecl under. ung control during ucurly thirty jeare, what hould cement their patriotiom, and I uleo know that you could increnoc rour forco by luundreds of thousnth if you would onls hare something defiute on paper, so that a man' who roluntecrs suight buow that when he left his coplosment and his howe to defend all the rest of the people who did not go aroay, und all the property. of ichich the oicus so, litlle, ha fhould bo assurod that thoec whom he left at home would be properly carcd for, and not treated as peupers, or left to the tender mescice of the broker or relicring officer, or relegated to the workhouse.

Colonol MACFis: I risq with great difidence to epcal in ouch an andicnce 28 this, dut. I way sy . I joincd the Yoluntecr Forec in.1859, and hare had, I.think, as nuch crpericnec se auyone in this room. For ninc revir I scrred is a privite, and for the remainder of the terin I hare been an Oficer, and for serentecen jears a Commauding. OAicer. I entircls diesent froni the ricw. put forward by Colonel Howiend Viucent, and wy reweon for. doing so. is explainel in the 20th paragraph of the puper resd by Colonel IInddau, nanels, that "Toluntcers are cirilians first, and Eoldiers afterwarls," for that is what the War Office and the authoritics aro rem njt to forget. It is all.rery: well to sny that when thej arc called out for active scrrice thoec who remain at home should pay for their wircs and fandices, but I hare lnown mans cascs of men bing asked to resign theis cmplojuscrit.becanee thes wrut for a weck into camp. Sucli crocs do oceur. Colonel-Howard.Tineent spole about Iurgo cinployers of labour, and mentioned the iarac of Messrs. Shoolbred. Of course it is rery patriotic of JIcsers. Slioolbred to pay what they do, but I think thes should not be cullicd upon to do it--no one should be called upon to put his lands into his pocliets in that munner. The countrs gencrally sliould proride for tho Yoluntecrs, and it should not be left for prirato firms to do it. It is all rers xell for lerge cmplosers of labour to tale such stept, but take the casc of the sniall cuployer, who has but two handa to do the whole.work. Onc of them goes awar for a weck's cump, and the other is left to do the work. Then if lic goes aigainst the will of his caployer he is turned out of his cmplorment or threatencd, and he cannot go to camp. I think the difficulty is rery great, and we ouglt to recognize that the men are cirilians first and soldiers aft crwands, which we do not oufieiently do at present. I $\mathrm{am}$ not at all criticizing Colonel Hoddan's paper, becauso in $\mathrm{my}$ experience I nercr came across a paper written so much in the interests of the Toluutcers as this one: I mas mention that I hare pointed out to Colonel lladkan a suistake occurring in tho 4th paragraph, which he line promiecd to ect right.

Mujor TODD, Middlesex Artillery Volunters: The questiou before its, I take it, is the defence of tho United Kingdon, and therefore I hope you will allow we to rungo a little further than other. speakers hare done in mnintaining that the rcry first thion that should bo donc is the etrongthening of the Nary, so that our food supplies mas. be all right. At tho samo tiune, eccing that it.rill take three or four ycars bcfore re can get the rcseclo that are required, is it not madncss on our. part to leare our people unprepared for war, or to defend their country from inrakion? dro we going to be dingracel again, as we rere in the Crimcan War, hering to hire German soldicrs to come.licre and idefend onr rotucn and children. $I$ think it ras.the most diegraceful thing I cres eat in

I A nizapprcheneion which was corrected by the Chairman:-ED. 
wy life. I remember when I vecnt with my fathe: to-Folkcstonc I saw German soldicrs doing Eunlishuen's duty. I said to my futher, "Who are theso men?" I luwl becn used to sesing our long-serrice soldiers there, but when I sam these men I was astonished. JIy father said, "These are German mereenn ries." I replied, "I will do all I can when I get to be a unan to nlter that slate of things," and I have bece trying to do so since. That is why I joincl the Voluntecr Force thirty Jears ago, and assisted in forming what is now a rery large battalion. I brought wy sons up in the same ras; thex were both commissioned when they were ecrentem, and passed through Woolwich and Sliocbury. I then took then to the infantry barracls of the Coldstrcam Gunrds to serre their time there, so as to be able to ctrill their nes, for I don't belierc in Officers taking their men in Huuteon cabs, when ordered to march them fron one purt of town to the other, but bclicro they should be able to train their men ut infantry drill, and so more their men as infantrs, as well as at their crtillery work. I then puesed them through the cavalry, so that you ece I hare some strong motires in epcaling in the was that I do at the present unoment. - You will caclise my waruth if I say that I clo not consider an Finglishanan is kortlyy the name of au Engliehmen unless ho belongs to some scrice. Wlicn we started the Voluntecr Force ne worled hard; wo truinct our fellows in boxing, fencing, and in riding, so that we rere able to get up the Rosal Military Tournament, which I had the honour of promoting with General Burnabs, some ten ycurs since, and which has donc go much towards fecding and schooling the orphans and riclows of our eoldiers. I hope the romen of this country will refuse to hare anything to do with uneu who will not only sny they are prepurcd to defend their country if it is attacket, but will prore that thicy are prenared to defend it by the practice and stuly of drill and of the acience of wur, the sane as a man should be able to box in order to defend his omn women and children. 'H 'Hat is my was of looking at it. We are coming to the times of the surrival of the fittest, und it is time the IIousc of Commons looked at this question from that strong point of ricw. Instead, wc haro the wasto of timo which is going on in the Ilousc at the prescat moasent, and which is a disgrace to the countrs. Unlces re arc back to buck in this matter we shall be like the single reed, and not like the bundle of sticls. " $\perp$ house dirided sgainst it self will f:all," therefore all classes of the community should worl together to sce that the country is prepared. Nerer mind the cxpense! What has the Trcesurr to do with it? We are the tarpnyers; we hare been giring our time to the Serrice. We hare been told that Messrs. Sloolbred gire noney to support their company; God forbid that this should happen in eny regiment! I would rcfuse to find the cquipment. It is a disgrace to the nation that wo should be called on to cquip our men. We are not beggars, and will not accept charitable contributions; let the country find the guns and cquipment, with ranges, de.; we gire tho time and labour.' I say the whole of the Toluntecr Forco ehould be first equipped, and then the Ninrs can go on building in tho meantime. Why should we bo protected by the Ninry? As Finglislumen we are not morthy tho name if we are not prepared to cleferid our shorcs. In caec the Nary got tho worst of it, as might happen, and the enewy counc on shore, then hor sliall wo protect our shores? There has been an immensc anount of talk about defending the heart of the countrs, meaning Londow, us two anny corps. ITe ece these two army corps on paper, but ro liare nerer scen them on the ground. But cren supposing there are two arms corps to defend the heart of the country, I defs those two arny corps to defend our shores. When I was a pupil of Iangban's, and also practiscd with forcing nasters, did thes tell une to defend my heart as the only part of wy anutomy to be defended? Certainls not. Thes taught me to defend any part of my anitons that night be attacked to the beat of ms power, therefore we unust be prepared to defead crers part of the anstoms of our country in the same way. You must equip jour men; Jou must do all this sort of thing. And then look at the good cifect tho practice of drill and discipline liaz upon the men themsclecs. It has clone a great desl of. good; many men who would hare been rery bad cheracters are nom firt clwas inca, simply through passing through the Voluntecr Force: And then look at what these nien are able to do. I don't say it out of mere brag, but this jear I took the Silrer Cup witli cightecn of my young men, that I had only had two jerrs in my batters. 'Tlies took it. for cxercising a 40 -pr., although we had to competo

$$
2 \text { 24 } 2
$$


ugilinst the arsenal men who cauc from Woolwicl. I eag if you will only train these men you ought not to put them to a penny expense; it is good enough for them to gire up their time and thcir leisure, and to goand do the rork, and prepare themsclves to defend the country. We are told that the country is in danger; cach party in politics tells us eo; cacli party in the country tells us we are dependent on tho Nars. They ray sou nre in danger. 'This would not bo the case if the public would only look at the question calınly, and if it wero put before them bf the autloritics in a clepre and found munner, that crers nan, I would wap crery male abore sixtecn Jears of age, capable of doing duts, should be called upon to join the Voluntecr Force, and puss ns cficients. The fact of harine: to do trenty drills a jear is no great hardship; iny men do 100 , and I do is with them. If erergoue should be compelled to do twents drills a gear, and to pass slso for shooting, Jou must then hare butts all orer the countrs. the gamo as our forefathers had at the doors of the people. I don't mean a single butt, liko that at Wormwood Scrubs, where they put a prison at the cad of it to stop slooting there. I sny jou ought not to aboliob a single butt, but jou should increars them all orcr the counirs, where the people may go and hare some practice before they out on their work in the morning, or after thes get home from their work at night, because I find that the men sre willing to get up at fire o'clock for the purpose, if tlicg get tlio chence. We muet usele crers man pass his eraminations in drill and in the use of the Morris tubes, and get the butts in the meantime. If jou will only do that, we shall always be able to mect our cuens. Let the drmy go abrosd, let them go to our cosling statione, Colonics, send them anywhere jou like; becauec wo should hare our men ready at anj spot that might bo attacked ; we cao defend our own shorcs, and if we cannot defend them, we deserro to looe them.

Licutenant-General Sir Heses Harelocs-AlLdx, U.C., M.P.: I hare been rery much struck, Sir, by some remerks which foll from the lnot speaker, and in nothing do I agree with him more entircly then in that which I hare accertained by my own experience, thet the time has almoet come when you hare got to the limit of rrbat the Yoluntecrs may be expected to do as to putting their hands in their pockets. I beliere that there is no limit whatsoerer to tho patriotism and the good spirit that they dieples, and aleo the crtent to which thes are ansious to arail themselres of erery posaible opportunity of military instruction. During the eloort time that I barc had tho lonour of holding my present poet I hare found that there are no dificulties raiecd on the part of the Volunteers, although there may be on the part of the authoritics, who to s certain extent do not appcar to apprccinte ns much os they might do the adrantage of placing facilities in the Voluntccrs' was which tho Folunteers themeclres desire in order to mate themuelree militarils clicient to ans cxtent poseible. It is in conncetion rith that thet I ohould like to say that I think the fact has not suficiently impresecd itself on those in authority that the time has now definitely come when, if the Voluntecrs aro to take part in the organization of this country for national defence, when the regular forces mas be withdrarn under any circumstances, such as the last epenter las forcsbadoned, jou cannot crpects the Foluntecrs or their OAicers or supporters to do much more pecunierily than they have already done. Men and Oficers are ready to gire their time and their leisure, thes contribute greatly in moncy aleo, but I think, if thes aro to be organizcd, as wo hope thes arc, cficctircly 25 ficld brigades, one of the first steps towards that should be that the Secretary of State for War should recognize that crery article of their cquipment ought, as far as possible, to be supplicd to them at the cxpense of the nation at large. How is it powible, for instance, for their carriage to be organized 00 that thes can go out and more in brigadcs unlcss a little more liberality is shown in the matter, and induecments are held out to people to proride the men with the neccesery horscs and carringes? As regards cquipment, onc difficults is that jou cannot abeolutely in certain months get the battalions in brigade together at all, simply becauec they could not undertake the railway journes becausc thes hare no great coats. Fou cannot aet $n$ man to sit for hours in a railwuy train in wintcr without a grcat coat. Then in the matter of leggings, and boots, and a mmunition-pouches, and other facilitics for carrying ammunition. I think all those thing are matters of abeolute neceseary equipment and ought primarily to be supplicel b5 the Gorcrnment itsclf. As regards one point, perhaps Colonel Haddun rould 
permit me to sag I think le lias fullen into sonac cror. Witlout speaking of a matter which mingt be supposed to be secret, I was onc of those cntircly opposed d:ast year to tho Natiounl Defenec Bill in the slape in which it at first stood: and nlthough I for one did not oppose the Sccrctary of Statc for War upon it openly, I liad no licsitation in cxpressing to him the rices which I lnow are held by a great part of the Voluntecrs in the North of England, nawcly, that if the compulsory clisuses as thes then stood had becn carricd out, tho effect on the Yoluntece Forec rould hare becn that thes would probubly lumo led to the disbandment of hinlf the force. I think Coloncl Haddua gocs to this point, that under a futuro modifiestion of this bill-which we hopo waj be brought in, perlaps this gear or the scar after, when tho authoritics hare had more cepcricnco of tho rcsponsibilitics of roluntecrs under tho new organization into mobile brigades-some of the offendirc and harmiful features of the lato Bill mas be struck out, and a better 13 ill framed. 'llie first step towards that is, that it fluall be done in accordance with the wislice of the Voluntcers themselres. I should like not only to asecrtain, if possible, the opinion of crers Commanding Ollicer, but also of crers Onicer, and almost crery indiridual man. I nas sas that I mysclf, when tho Bill was first intruduced, suggested to the Secretary of State for lliar that it slould bo suspended for tho present until lie liad asked crery Commanding Ollicer of erers corps in tho linglom, bs circulur, crastly what the men would think it right to do, and what they would think bejond the linits of what thes should be called upon to do as Voluntecrs. I beliere, if the Bill liad been passed upon information obtained in that way in the first instance, there would hare becn no difficulty at all in its unircras applicution throughout the country. I deprecate in the strongest poosible way tho ides that Voluntecrs elould in uny was be treated like the other defensiro forces of the country. They arc, in the first instance, civiliano before they are soldicrs, and the only ray of getting the utmost roluntary ellicicnes out of thein id to mato your ojstem applicd to then as flcsible as possiblc, aud to cndcarour to caliat tho actirc co-operation of ercrs. man bs suiting your militars circumstances to his purticular indiridual circumstunecs. Then as regarde the future, I trust that that coursc will be pursued, and that the authoritics will at cach step procecd by first aecertaining tho indiridual opinion of the men, because it must be rccollected that a Voluntecr Forco is not composed of Obecrs alone. The man, after all, is the indiridual unit that you rant to get at, because if ho docs not choosc to couno out he won't come out. I hope further steps will nlso be talen as to supplying qualified Staff Omicers for tho mobile brigades. Tho suggestion made by Colonel Hedelen that a smart ddjutant should be attaclied to tho Horse Guards is, I think, not necessery, because we liare already the Inapector-General of the duxiliers Forecs, who lias at his disposal the rers best practical information as to crers brigade and Dirision, and erers indiridual reginent; and I trust one of the steps that will bo taken xill be to supply cach of tho brigatles with a thorougly qualifich Stzef Offcer-not necessarily regular OMicers-but if in some cases it may be found that tho voluntece 13rigacle. Jlajor would be thobest Brigade-JIajor, at all creats the rerg best qualificd Oficer should be attnclied for tho oneroug duties of tho Staff to cach brigndc, which demand a ect of qualitics which it is almost inpossible to unite in onc man. duyone conaceted with Voluntecrs lnows how rers desimble it is that their rough points slould not be touched, and that in dercloping their nilitury form they should be led rather tlian driren. I thank you rers much for allowing sne to male these renarby. I lnow I nin representing tle riers of other Guncral Offeces in tho same position as meeclf commanding roluntecr brigudes, that they clesiro to hare crers possible information from the iudiriduals conpouing those brigades, and lope that the information that mas be gathered in the nest fer montlis inas lead to maling our Voluntecr Force more effectire thun it is ut present, sud will carrs with it the roluntary co-operation of the great bods of Voluntecrs for the great work of national defence.

Colonel IIU YsEL: I think me urc greatly indebted to Colond Haddan for giring us the nost farourable opportunity for discussion that Voluntecr Oficers lare had for some tine. For nis onn part I was strongly in farour of the retention of the roluntecr clause in the Defence Bill of last jear. I felt it was a greut pronotion of the Voluntecr Force that it should be so included, and that a greut blow rue 
dealt to it when it was etruck out. I do not wssclf belicre that any non who enrols himself in the Toluntecr Serrice would coneider, for one moment, whethep ench a clauso rould offect his future prospects. I think lic carols for the pure lore of soldiering. I think also that we are perlaps apt to orerlool what the condition of the country rould be supposing such a clause crer were put in force. Where would business be in the caso of threatened inrasion? Would not the whole conn. nacreial arrangements of the countrs bo cntircls upect? Would not the nution bo acized with a nilitary furore which would induce men to throng the military cent ren and colist wholcenle? I thiol there is not the emallest fear in tho world that the Toluntecr Forec will bo affected in any way in strength except farourably by the replacing of such a clause in the Defenco Bill. I ehould, therefore, strongly adro. cato that sone steps be talen by the representatires of the Voluutecr Foree in the Housc of Commons for tho immediato re-introduction of some such clausc. I dn not kny a compulsory clause, but that power should be rescrsed to call out such portions of the force as would bo able to go out on these ocensions. There would in such a casc be.no inridious distinctions. I might not myself bo able to go out, but if aty one in ms cmplos, who, I could sparc, wished to go, I would reaclily let lim take those duties which he might be called upon to perform in the absence of the regular Army. 'That I bclicve is the raison d'etre of our cxistence, and there. fore we should hare erery opportunity provided for us to excreise oursclres on theso occasions. A rery large proportion of the force would be able to go out in the crent of an army corps being callexl abrond, and thes would be relievel from time to time; but renlly I nm quite certain that if such powers were resersed it would not affect the Voluntecrs further than to improre ilicir status in public opinion. Now, with regard to the question of brigade organization, I think it is a rerg grand step and onc which ought to hare becn taken long ago. . It is siniply what was wanted. It is an initiatory step, but it is onc of cnomous importance, and can be carricd out with very little trouble and with no espense whaterer. Colonel IIrldan puts lis finger on a grcat slefect in the Foluntecr Scrvice, riz., the want of bnowledge of the requirements of tho Service at Headquarters. I suegest, Fith all duo deference to the Brigadier-Geacrals, that this miglit be donc through the brigade organization. It was impossible to help, under the circumstances, tlie rery great rariation of conditions under which the Foluntece Forco mas formed. But military bodics require uniformity, and the rariations in equipment, in cliscipline, in commund, and in erersthing connected with the corps are enormous in the Foluntcers of to-day, and they counteract, to a grest crtent, the efforts of the suthoritics to produce any uniform action. I tales it it would be cass for Brigaclicrs -nithough it rould require somo considerable increase in their Staff-to brep in duils touch with erers reginent, to ascertain croctly the mhole of the details of their interior cconoms; to bnow, as well as the Commanding Offecr and Adjulant hinsclf, the ins and outs of erery reginent, and, as far as possible, to put their discipline and interior economs, and eren their financial afrairs, on an cqual footing. Througly them the anthorities, the higher authoritics at the War Ofice, would buow rlat reginents nro wanting, as to details of cquipwent, and the rarious diff. cultics regiments suffer under for want of drill ground, want of shooting nccom. modation, That regimente are able to do certain drills in the Icar, to go to Aldershot, or so on. Ercer cffort should be male to introduce one uniform system. Whiv should one regiment be able to build handsome quarters while anotlice has to drill in the strect? Why sliould one regiment linvo a splendid ritle range elose at liand wilien snother has to go 20 miles out? All these questions are incre matters of trouble. It is not a matter of expense at all. A mere Act of Parliament would produce tho ground for rille ranges. Wo hare miles and miles of ground on the rirer inarshes, for instance, on which rife practice could be made; a nere Act of Pnrlinment could enforce the purchisse of ground wisch rould produce a rauge, and the Toluntecr Force would be only too glad to repas the Gorerument by a rent. Tlic eame thing mar be saicl with regard to drill-grounds. A merc ict of Parlia. ment would be required for the acquiring of property in I.onclon to accommodato the rarious regiments according to their necessitics, and they could be repaid out of the Capitation Grant. I rin sure I nm quite riglit in saying if anybolly mould tuke the trouble-that is all it nants. That haring been ilone, we slould get one: 
stcp towards a completc army. As to transport and greut coatz, we do not almays waut to carry greit conts, but ro should rery much like to bnow that we could always get them when thes are required. We do not alwass want to be followed about by carts and that sort of thing, but ne ghould rers nuch like to know that they are fortheoming when required. I do not ece why reginental Commanding Olicers should be required to nate inquiries as to whether carts could be obtained if wanted; why should not that be dono on a system from Ileadquarters; why should not they be npportioned to us when wo are called out? I think it would be such a rery casy unatter-it only wants somebody in higl authority to more in it. ${ }^{1}$ There are many other difficultics which I cannot go into which would be orercome in that way. Iset us tile tlic question of the want of OAliccrs. 'To ms mind, to a large crtent, it is caused by the Service not being good cnough. So much is required and so little giren-and really it is getting liarder and harder erery day. I do think that if steps of this bind were talen, and wo were snade to fecl that we were a real actual forec, not doing just as wo like, ono regiment liaring beautiful lecadquarters where thes can holl dances crers night, and another regiment haring no lieadquarters at all; if it were understood that there was one uniform s5stem, that we all hacl cqual accomusodation and nelrantages, and that if we did not all do well alike we should be dealt with accordingly, the public nould then know that we werc a good and raluable force, and certainly we should bo well oficered.: It is a most melancholy thing to sce a Secretary of State for War staud un in the Ilouse of Commons und say that from rarious reports he had receired, some roluntecr regiments were good enough to be put alongside regiments of the line, and others could not be trusted to face a disciplined forcign army. Why should that condition of affuirs crist? Who is responsible for it? Is not the Sceretary of Statc for War himsclf rcsponsible? I do not bnow anyone clso who is. I think by the crercise of common-sense all these dificulties might be got orer, and the Toluntecr Force would therebr bo greatly bencfited.

Mr. J. K. JI AcDoswiLL: Might I say one word with regard to an obserration that fell from Coloncl IIummel? IIc said the dropped clauscs mould not be objectionable because the country would be in a peculiar state of ferment at the time that mould come into operation. The position of thosc who, lite mysclf, opplosed thesc clauscs was, that by tho conditions they might legally bo put in force when the country was not in such a condition of fcrment.

Colonel BLEsDEI.L, M.P.: 'There is a point that has cume under my notice, haring the honour to commiand ono of the roluntecr brigades, and that is tho diticulty of getting anjone in the country to tale the initiative in getting up a fund to obtain the equipinent to completo tho different reriments. The Lord Mayor of Iondon has shown his appreciation of the necessity of the Foluntcer Force being equipperl. He has passed 'lemple $\mathrm{Bar}$ in taking in the metropolitan Voluntecrs; and if a ease crer aruse in which the jetropolitan Voluntecrs were used, the roluntecrs of the country would also be required. I would thercfore strongly urge the Iord IIayor to male the fund he is rasing a national fund. Is far as 1 could judge, I think it would cost probably something betwecn half a million and a iuilion to complete the cquipment of the Volunteer Force-that is, les than the cust of onc ironclad; and if our force was properls equipped-cren if we were to look upon it from the nival aspect that liaz been so much spoken of-it would free our Fleet to an estent that would be far more than the ralue of a single irunclad. I am ansious to urge that strongly, because I find in the countrs while people are

1 It nppcarcel from the obsertations of the gallant Chairman that I dill not unse my sclf clcar on the subject of trunsport. I hold that it should be organized by the Wiar Office on a wisle and comprehensire basis, the whole carrying capacits of the countrs being registered and apportioned to districts and reginients.

$=$ The report ounits somo remarls by which I me:nt to conrey the opinion that from the peculiar conditions, chicfly triditional, but liaryely csistent, of the Yolunfeer Force, the position of an Ontecr is not encluet! with such a degree of clistine. tion, in complirison with the other Serrices, as to counterbalance the grest and increasing work it dewands. 
friendly disposed toxards the equipment you cannot get anslody to talic the initie. tire. There is another point $f$ an anrious to sag a word upon, and that is this question of the clauses in the Defence Bill of last year. I think they want to be more thoroughly understood by the Toluntecr Forec. IIs impression is the Srere. tarj of State for War was ansious to tale a power, but that the Voluntcer Foree might hare trusted him not to hare cxcrcised that porrerin an improper war. Because, you must recollect, you cen only call the roluntecrs out in casc of actuid or appreherded in rasion. Well, it enight be rery objectionable to a Government to hare to say thes appredicndecl inrusion: if they did, the Gorernment would not like to hare to saj so: therefore it wants somcthing morc. Now, what was sug. gested to me-and what appears to me to be right-is that a Gorernment ought to hare the right to embody the Voluntecr Foree if ther are prepared to announce on their responsibility, ns a Gorermment, that they will bring in a lill to suspend the "Ballot for the dilitia Suspension Act." This would show the country that there really was a criais which required the Voluntecrs to be cmbodich. If that Act were suspended erery rich man, or in fact crerybody, would feel that he was liable to serre in the militia, and that therefore it was ncecssary for him to do his ut moos that the Volunteer Fore which enue forward should fecl secure that there shoukl be scparation nllowinces for fumilics, aud that funds would be got up. I think if the Gorcrnnent, upon its respousibility as a Government, was prepared to declare that the Ballot Suspension det for the militia ought to be suspended or repealed, that then you nould find you could usc your Voluntecr Forec, that then you would find the Foluntecr Force would come out, and no one would suffer; and if the Voluntecr Fore were properly supported by localities-localities who so supported the Folunteer Foree might tliereby prerent the necessity of the militia ballot being cnforeed.

Major BARsixgtox Foote, R.A.: I had not the slightest intention of epeaking this afternoon. I hare mysclf had nothing whaterer to do with the Voluntecrs escept that for sonio few years I used to go down on the Staff to Wimbledon, and I remember those times with rery great pleasure. I wish, howerer, to show god comradeship on the part of the am to which I belong. I am sure none of $\mathrm{u}_{3}$ in the regular Amy wish the Voluntcers to think that in anj great question of this sort thes are Ieft entirely to themselres; and I nu furtlicr sure I am only cxpres. sing the feeling of my brother Ollicers of the regular $\Delta$ rmy in saying that that is not the casc. We tale tho secnest interest in inatt'rs concerning the Tolunters and all that has to do with their progress, organization, and efficicney. Onc point brought forwand by two or three epeakers is that there should be plenty of rifle ranges and plenty of bults spread all orer the country, so that it nould be cass for Tolunteers to go out and practise rifle shooting before or after their regular day's rork. That is no doubt greatly to be wished, but it is rery dificult to attain. 'Ihe fircarms of the present day liare incrensed this dificulty. I belong to the Royal Artillers, and it may surprise manr to hear the range required for the guns of my own battery (12-pr. B.L.) is such that we hare only one land-range in tho whole of England where we can practise, and that is on Dartmoor, at Olehampton. We useil to have oflicr practice grounds, but they are uscless for this new gun. 13y that I do not mean to say the actual range we are firing at could not be obt:ined, but that is not the only question. It is the ricochet shot, where the shots nnay go on to. So then sou hare to consider for long-ringe rilles, with rery llat trajectory, not only the butts but the whole country. That is one difieulty in obtaining numerous rifle ranges. It is true rou do not want the ranges as extensive as we do for cannon, but still modern rifles and modern musketry do make it much more dillicult to get ranges which gire sudicient country bcyond, unles you have pre. cipitous hills or clifirs at the back. I The sum total-the essence of what most of the spcakers hare been adrocating-is simply znoncy, more mones. Nobody lass eaid that in so inany words, but that is what it comes to. I am sure crerybody wants the Volunteer Foree to be as cllicient 23 possible, but that efticiency unst touch

I I am alluding, of course, to practical work, such 23 firing other than inde. pendently and at unlnown ranges not only where indiridual - and indiridual firing alone-is practiscd. 
fiunce. Whether it is a question of equipment, or of rifle ranges to be bought, or butts to be built, of transwort, or of providing for the funilies of those who inar jossibly nt some time be crippled on actire serrice-crery one of these points means outlas. Most of them menn outlas now. Fiuipmeut, butts, ranges, transport - that means money at once to be roted, and we know that this nust coine before the House of Conmons, and re also lnow rers well that a great increase of

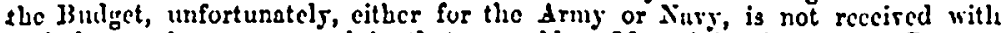
entircly uninimous apprornl in that assembly. My opinion is that any Gorernment-I do not care which party is in power-would be unwilling to ask for a large extru crpenditure, absolutely neccsidry as it is, unless they felt that tho public werc on their side, and that such an expenditure would be popular with the people generally. Of course it would be popular with us. After all, it secms to me that it is partly in the hands of the Foluntecrs themselres to convert the public. I little leareu will learen a whole lump. You hare a rery large learen in the rolunteer body, and if the whole of the Tolunteers will sct to work to consert the British public to the nbsolute necessity of this extru cxpenditure, it might then be brought forward with confidence. I am not adrociting public epealing, but quict tulking togetler orer the freside. If the whole of tho foluntecrs in the British Isles were really lonestly to sut to work, cach in his own circle, I renture to belicro the whole of the taxpajers of England might be won orer. The Qurcrnment would be perfectly well aware of this conrersion of the public inind, nad then, and flien onls, nould it be willing to ask for such a large extre outling as would be necessirs.

Colonel Iladds: : There was one mistnke I made in Clause 4. I snid," A recent cisc at Lircrpool afrords an crample of the troubles that mas ensuc from such societics atteinpting to deal with ordimary matters of a military nature." I was informed ofliciully-I may say ecmi-officially - that a certain socicty had been ccusured for some of its junior Odicers mixing themsclres up with the formation of a marching column at Easter. I hare sinee been informed that the Geaeral commanding that district received an csplauation from the Folunteer Offecr of the district, and he stated that he wus perfectly sutisfied with the explanation that that Oficer afforded. It is only an act of justice to 825 that I made the statement in perfect good fuith. I mas not aware at the time that the censure lud been with. drawn-cren if it were giren.

The Cralrsss: : My remarks will be rery brief. I may say, offlind, I think almost erery soldier agrees in substance with what the lecturer hins statcu-that the country has bitherto asked far too much of the Voluntecrs, and done far too little. I think ereryone agrees to that. But, gentlemen, it is in jour own hands. Ererg now and then you hare an clection; you send people to the IIause of Commons. If you would concern yourselres a little less whether he is a Torg or what is called a Libcral, and concern yoursclres a little more nbout the defence of the country and the Folunters, it would be better. I enjosed iwmeuscly the eloxucnt speceh of Major Todd. Ho has depicted rather a sorry uspect of things : my only cousola. tion is that he and men lile him haro done go much to retriere the negligence of the lazy ones. With regarl to his experiences when lie was joung, with reganl to the Germanz, it is no doubt true that the Kinglishman, well paid at hotne whion tho country is in a flourishing state, does not care to go abroal anywhere. There are, besides, only a limited number of us; and those Gerusuns, who irritated him when lic was a litile boy, were hired for the Crimea; and I beliere we only brought them home here to Fingland when, as usual, haring etarted too late, the Crimenn War vas orer before thes arrired. I was interested in telling you that because we did not cnlist the Germans to defend Fingland. His suggestion that we should enlist the lodies on our side ras carried out to our great detriment in 1891, for there is a country with which I had something to do, in South dfrica where they appearcd to hare carricd out his suggestion literally. There were three girls married on the morning on which we signed the Peace. I saw those threc girls, and tlics hat becn waiting from before the outbreak for tlicir marriage; but they said, "We do not want to narry till the war is orer." So that that suggestion has been carriel out by a mec which wre, unfortunately, once too unuch conteuned. I think Colonel Hummel wale a mistale in talking about the transport. IIe said we should find 
it. Well, I hare found that you men of busincsis do your business much bettep than/we do. We are finding the transport, because we gire you the money. In tho district from which I hare recently come, erery Officer who has been offered sum of mones las told me rerbally, and oflicinlly on paper, that with the allonance the Gorernment has giren him, he could find the traneport. There has been a complaint about great coats. Irany corps harc great coats, but if you aro.ap. pronching the Scerctary of State for $W$ ar and asting line for money, you muit espect he will be a little inquisitire as to what you clo with sour Capitution Grabt, as to whether it is giren amay in prizo mectings or as to whether it cuds in inducing the men to go into camp. You lare to consider that. I think you do not get nearly cuougla. I hare said so publicly and privatcly. I bure lept tlic crcam of the thing for the end. I consider the City has behared rather worse than ull the rest of England-with regard to the Voluntecrs. I scarcely lnow anyone in the City who lias conve forward in the was in which the country gentlenen hare done, and the Cit 5 has scemcd to haro not the elightest interest in jou. Well, I am happy to eas, with the present Lorl Mrayor, we hare fairly turned the corner, and ne shall all be now too gratcful to the City for wliat they are doing. I will, with your per. mision, read this paper: "The Lord Major would haro been present to-day but is letained at a epccial mecting of the Corporation. Ho proposes to raises a fund of $100,000 l$. for the metropolitan corps." He states "that this morement is alreadr epreading, and sercral Jlayors of large provincial towns are following his lcakl." It only remains for me, in sour name, to thank the lecturer for the interesting paper that he has read to us. 